\title{
Treatment of Landfill Leachate using Sequencing Batch Reactor
}

\author{
W.D.M.C. Perera ${ }^{1 *}$, N.J.G.J. Bandara ${ }^{1}$ and M. Jayaweera ${ }^{2}$ \\ ${ }^{I}$ Department of Forestry and Environmental Science, University of Sri Jayewardenepura \\ ${ }^{2}$ Department of Civil Engineering, University of Moratuwa
}

Date Received: 18-08-2013 Date Accepted: 31-03-2014

\begin{abstract}
In Sri Lanka municipal solid waste is generally disposed in poorly managed open dumps due to lack of liner systems and leachate collection systems. Rain water percolates through the waste layers to produce leachate which drains into ground water and finally to nearby water bodies, which cause degrading the quality of water. Leachate thus has become a major environmental concern in municipal waste management and treatment of leachate is a major challenge for the existing and proposed landfill sites.
\end{abstract}

The present study was conducted to assess the feasibility of the usage of the Sequencing Batch Reactor (SBR) in the treatment of the landfill leachate up to the proposed levels in the draft report of "Proposed Sri Lankan standards for landfill leachate to be disposed to the inland waters". Leachate collected from the open dumpsite at Meethotamulla, Western Province, Sri Lanka was used for leachate characterisation.

The SBR was constructed with a $10 \mathrm{~L}$ working volume operated in an 18 hour cycle mode and each cycle consists of $15 \mathrm{hrs}$ of aerobic, $2 \mathrm{hrs}$ settle and $0.5 \mathrm{hrs}$ of fill/decant stages. The Dissolved Oxygen (DO) level within the SBR was maintained at $2 \mathrm{mg} / \mathrm{l}$ through the aerobic stage. Infeed was diluted with water during the acclimatisation period and a leachate to water ratio of 55:45 was maintained. The removal efficiencies for different parameters were; $\mathrm{COD}=90.5 \%, \mathrm{BOD}=92.6 \%$, $\mathrm{TS}=92.1 \%$, conductivity $=3.9 \%$, alkalinity $=97.4 \%$, hardness $=82.2 \%, \mathrm{Mg}=0.5 \%, \mathrm{Fe}=94.2 \%, \mathrm{Zn}=63.4 \%$, $\mathrm{Cr}=31.69 \%, \mathrm{~Pb}=99.6 \%$, sulphate $=98.9 \%$, and $\mathrm{P}=71.4 \%$. In addition, $\mathrm{Ni}$ and $\mathrm{Cd}$ were completely removed during a single SBR cycle.

The dilution of leachate in the dumpsites using municipal wastewater, groundwater or rainwater was identified as the most cost effective dilution methods. The effluent from the SBR proposed to be further treated using a constructed wetland before releasing to surface water.

Keywords: Sequencing Batch Reactor (SBR), leachate, conceptual design, landfill

\section{Introduction}

Generation of solid waste is inevitable in the daily activities of humans and animals. As humans strive to keep the environment clean to avoid infectious diseases from bacteria and viruses by dumping solid waste in landfills, they create other environmental problems. Therefore decomposing waste within the landfills generates greenhouse gases (methane and carbon dioxide) as well as the production of a

* Correspondence: madhurangiperera@yahoo.com

Tel: +940715344909

ISSN 2235-9370 Print/ISSN 2235-9362 Online @ University of Sri Jayewardenepura

82 
liquid known as leachate when precipitation infiltrates. Leachate is highly polluted due to high content of ammonium ions and organic compounds (Welander, 1998).

According to Renou, et al. (2008) the landfill age, precipitation, seasonal weather variations and the types of waste and their composition will determine the final quality of the leachate. It has been also stated that landfill age is the major factor affecting the final leachate quality but Chian and DeWalle (1975) states that degree of solid waste stabilisation is also important.

When leachate moves downwards from landfill into ground water table, ground-water gets contaminated as a result of infiltrated precipitation (Fetter, 2001). Groundwater and surface water are the main sources of potable water, therefore is necessary to avoid contamination of the potable water sources. Leachate production in the landfills cannot be completely avoided therefore reduction of leachate production and treatment of the generated leachate, to eliminate or to reduce the level of contamination are practically used.

Leachate are often discharged to local wastewater treatment plant in order to obtain sufficient treatment, though it may be advantageous from an economic point of view to have final treatment of leachate on site. During the recent years, many new methods, i.e., physicochemical, biological and combined biological and physic-chemical have been proposed and tested. Reliability, cost effectiveness and simplicity are higher in biological treatment therefore it is commonly used in treating leachate with high BOD values (Renou et al., 2008). Aerobic biological treatment results in a high effectiveness in leachate treatment of young landfill leachate with $>80 \%$ BOD, 60-80\% COD, >80\% Total Kjeldhal Nitrogen (TKN) and 60-80\% SS removal. (Renou et al., 2008) Fresh leachate has a high biodegradability according to XU et al. (2009).

In Comparison with the other biological treatment methods in terms of treatment efficiency, space utilisation, installation and operational cost, use of the sequencing batch reactor (SBR) technology for primary biological treatment of landfill leachate has proved to be a reliable and robust strategy (Ifeanyichukwu, 2008).

\section{Methodology}

\subsection{Study Area}

The Meethotamulla dumpsite is located in Dahampura Grama Niladhari Division of Kolonnawa Divisional Secretariat Division in Colombo District. The geological co-ordinates are: $6^{0} 56^{\prime} 6.4^{\prime \prime} \mathrm{N}$ and $79^{0} 53^{\prime} 13.9^{\prime \prime} \mathrm{E}$. The site at Meethotamulla is being used for the disposal of the solid waste generated in Kolonnawa. The dumping site is 16 acres in extent and is not a properly managed sanitary landfill site. The collected waste in the Kolonnawa area is disposed in the landfill and 45,500 $\mathrm{kg}$ of waste is disposed daily. The open dump is more than 30 meters in height and due to low maintenance, it has created most unhealthy and insanitary conditions. The landfill is now producing methane gas due to the collection of waste over many decades. The untreated leachate flows to a stagnated water body which is adjacent to the dump.

\subsection{Sampling of landfill leachate}

Landfill leachate was collected from the Meethotamulla dumpsite which is in active operation. Samples were collected in polypropylene bottles and leachate was collected with minimum headspaces to minimise aeration. Sampling was carried out from May 2013 to June 2013. The leachate characterisation was done using twelve samples. The collected samples were transported to the laboratory and stored at $4{ }^{0} \mathrm{C}$ until analysis. 


\subsection{Leachate characterisation}

Mainly, four groups of pollutants, general water quality parameters, anions and cations, organic pollutants and heavy metals were measured in collected leachate samples using standard methods. Dissolved Oxygen (DO), $\mathrm{pH}$, electrical conductivity (EC), suspended solids, ammonical nitrogen (TN) and total phosphorous (TP) and sulphates were measured as general water quality parameters. DO, $\mathrm{pH}$, EC were analyzed using DO meter, $\mathrm{pH}$ meter, and EC meter, respectively. Suspended solids were measured by filtration followed by oven drying. Total phosphorous were analyzed using Kjeldhal method and colorimetric method (UV mini, GBC, Australia).

Atomic Absorption Spectrometric (AAS) technique was used to measure cations $\mathrm{Mg}, \mathrm{Ca}, \mathrm{K}$, and $\mathrm{Na}$ in collected landfill leachate. Chloride anion was measured using the potentiometric method. The amount of organic pollutants in landfill leachate was measured in terms of Biochemical Oxygen Demand $\left(\mathrm{BOD}_{5}\right)$ and Chemical Oxygen Demand (COD). Standards methods were used to analyse $\mathrm{BOD}_{5}$ (Wrinkle method / DO meter) and COD (Dichromate method) in leachate samples.

\section{Results and Discussion}

The physical, chemical and biological parameters of leachate were measured in accordance with the standard water quality measurements. The results obtained are given in Table 1.

Table 1: Leachate Characterization data.

\begin{tabular}{|c|c|c|c|c|}
\hline Parameter & Units & Range & Mean & St. deviation \\
\hline Temperature & ${ }^{0} \mathrm{C}$ & $29.0-30.0$ & 29.5 & 0.577 \\
\hline $\mathrm{pH}$ & & $6.73-7.05$ & 6.909 & 0.135 \\
\hline Conductivity & $\mathrm{ms} / \mathrm{cm}$ & $27.00-30.00$ & 28.525 & 1.305 \\
\hline Odour & & & Unacceptable & \\
\hline Colour & & & Unacceptable & \\
\hline Alkalinity & $\mathrm{mg} / \mathrm{l} \mathrm{CaCO}_{3}$ & $5,250-6,000$ & 5,575 & 361.709 \\
\hline Hardness & $\mathrm{mg} / \mathrm{l} \mathrm{CaC03}$ & $2,450-2,875$ & $2,588.750$ & 193.665 \\
\hline COD & $\mathrm{mg} / \mathrm{l}$ & $57,143-64,165$ & 60,367 & $2,886.377$ \\
\hline $\mathrm{NH}_{3}-\mathrm{N}$ & $\mathrm{mg} / \mathrm{l}$ & $19.20-25.30$ & 21.92 & 2.551 \\
\hline BOD & $\mathrm{mg} / \mathrm{l}$ & $18,480-24,570$ & 21483 & $2,930.943$ \\
\hline Chloride & $\mathrm{mg} / \mathrm{l} \mathrm{Cl}^{-}$ & $250.62-304.56$ & 278.293 & 26.848 \\
\hline $\mathrm{Mg}$ & $\mathrm{mg} / \mathrm{l}$ & $298.40-383.53$ & 335.429 & 35.505 \\
\hline $\mathrm{Ca}$ & $\mathrm{mg} / \mathrm{l}$ & $\begin{array}{l}1,632.10- \\
2,414.39\end{array}$ & $2,055.185$ & 339.276 \\
\hline $\mathrm{Fe}$ & $\mathrm{mg} / \mathrm{l}$ & $7.76-8.17$ & 7.924 & 0.181 \\
\hline $\mathrm{Zn}$ & $\mathrm{mg} / \mathrm{l}$ & $0.33-0.66$ & 0.481 & 0.142 \\
\hline $\mathrm{Cr}$ & $\mathrm{mg} / \mathrm{l}$ & 0.06 & 0.061 & 0.002 \\
\hline $\mathrm{Cd}$ & $\mathrm{mg} / \mathrm{l}$ & $0.00-0.02$ & 0.015 & 0.009 \\
\hline $\mathrm{Pb}$ & $\mu \mathrm{g} / \mathrm{l}$ & $18.85-96.98$ & 57.912 & 55.248 \\
\hline $\mathrm{Ni}$ & $\mu \mathrm{g} / 1$ & $649.72-734.04$ & 680.461 & 39.874 \\
\hline TS & $\mathrm{mg} / \mathrm{l}$ & $41,748-44,748$ & $43,176.500$ & $1,281.568$ \\
\hline Sulphate & $\mathrm{mg} / 1 \mathrm{SO}_{4}{ }^{2-}$ & $3.13-7.71$ & 5.122 & 1.950 \\
\hline Phosphorous & $\mathrm{mg} / \mathrm{l} \mathrm{P}$ & $6.27-9.15$ & 7.578 & 1.188 \\
\hline Total Coliform count & MPN per $100 \mathrm{ml}$ & $1,800-2,000$ & $1,887.500$ & 85.391 \\
\hline E. coli count & MPN per $100 \mathrm{ml}$ & $840-990$ & 902.500 & 63.443 \\
\hline
\end{tabular}


Temperature of leachate was $29-30^{\circ} \mathrm{C}$ and $\mathrm{pH}$ was $6.73-7.05$. Alkalinity and the hardness of leachate were recorded as 5,250-6,000 mg/l CaCO 3 and 2,450-2,875 $\mathrm{mg} / \mathrm{l} \mathrm{CaCO}_{3}$ respectively. The COD ranged between 57,143-64,165 mg/l, with ranges of 18,480-24,570 mg/l and 41,748-44,748 mg/l, for BOD and TS. The metals $\mathrm{Mg}$. $\mathrm{Ca}, \mathrm{Fe}, \mathrm{Zn}, \mathrm{Cr}, \mathrm{Cd}, \mathrm{Pd}$, and $\mathrm{Ni}$ were observed in the leachate. It contained 3.13-7.71 mg/l sulfate levels while the P levels were 6.27-9.15 mg/l. The total coliform count exceeded the recommended levels.

The leachate quality data were used in the conceptual designing of the Sequencing Batch Reactor to remove COD and BOD in the resultant effluent. Metcalf and Eddy (2003) conceptual designing of SBR was used to obtain the design parameters for the SBR given in Table 2. The Kinetic coefficients for the SBR were recalculated for $29.5^{\circ} \mathrm{C}$ (the temperature of the infeed). In the initial stage Activated sludge from the Raddolugama Housing Scheme water treatment plant (Seeduwa) was added to SBR prior to the addition of infeed.

Table 2: Sequencing Batch Reactor design parameters.

\begin{tabular}{lcc}
\hline Design Parameter & Unit & Value \\
\hline Average Flow & $\mathrm{m} 3 / \mathrm{day}$ & 0.0134 \\
Number of tanks & $\mathrm{Nos}$ & 1 \\
Fill time & $\mathrm{hr}$ & 0.5 \\
Aeration time & $\mathrm{hr}$ & 15 \\
Settle time & $\mathrm{hr}$ & 2 \\
Decant time & $\mathrm{hr}$ & 0.5 \\
Cycle time & $\mathrm{hr}$ & 18 \\
Total SRT & $\mathrm{Day}$ & 0.967 \\
Hydraulic Retention time $(\tau)$ & $\mathrm{hr}$ & 60 \\
Tank Volume & $\mathrm{m}^{3}$ & 0.0335 \\
Fill volume per cycle & $\mathrm{m}$ & 0.0100 \\
Fill volume/ Tank volume & $\mathrm{m}$ & 0.3 \\
Decant depth & $\mathrm{m}$ & 0.12 \\
Depth of water & $\mathrm{m}$ & 0.4 \\
MLSS & $\mathrm{g} / \mathrm{m}^{3}$ & 3850 \\
MLVSS & $\mathrm{g} / \mathrm{m}^{3}$ & 2569.796 \\
F/M & $\mathrm{g} / \mathrm{g} . \mathrm{d}$ & 1.671 \\
Volumetric BOD Loading & $\mathrm{kg} / \mathrm{m}^{3} . \mathrm{d}$ & 8.593 \\
Sludge Production & $\mathrm{kg} / \mathrm{d}$ & 0.133 \\
Observed Yield & $\mathrm{g} \mathrm{VSS/g} \mathrm{BOD}$ & 0.309 \\
& $\mathrm{~g} \mathrm{TSS/} \mathrm{g} \mathrm{bCOD}$ & 0.289 \\
bCODe (expected ) & $\mathrm{mg} / \mathrm{l}$ & 3000 \\
BODe (expected) & $\mathrm{mg} / \mathrm{l}$ & 1875 \\
TSSe (expected) & $\mathrm{mg} / \mathrm{l}$ & 800 \\
SBR Tank Depth & $\mathrm{m}$ & 0.45 \\
SBR Tank Width & $\mathrm{m}$ & 0.29 \\
SBR Tank Length & $\mathrm{m}$ & 0.29 \\
\hline & & \\
& & \\
& &
\end{tabular}

The working volume of the SBR was 10 liters and was operated in an 18 hour cycle mode. Each cycle consist of 15 hours of aerobic, 2 hours settle and 0.5 hour of fill/decant stages. During the aerobic stage, DO level within the SBR was maintained at $2 \mathrm{mg} / \mathrm{l}$. The SBR Sketch according to the design parameters is given in Figure1. Infeed was diluted with water during the acclimatization period, starting from 100 times dilution, then gradually increased the leachate volume in infeed to maintain a leachate to water ratio of 55:45 in the final stage. The variations of BOD, COD and TS were recorded for 109 days. Final effluent characterisation with the changes in MLSS, MLVSS and SVI were carried out from 
the $54^{\text {th }}$ day of operation. The final effluent quality results (Table 3 ) obtained indicated that the leachate is being efficiently treated through the Sequencing batch Reactor.

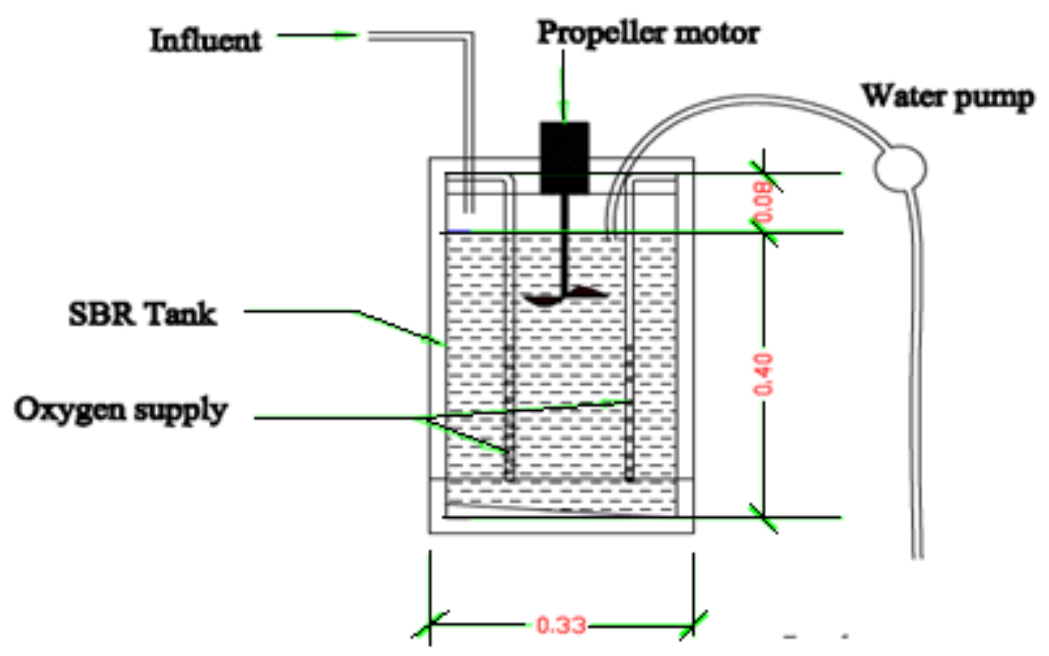

Figure 1: SBR sketch according to design parameter.

Table 3: Sequencing Batch Reactor effluent quality.

\begin{tabular}{llccl}
\hline Parameter & $\mathrm{Units}$ & Range & Mean & St. deviation \\
\hline Temperature & ${ }^{0} \mathrm{C}$ & $29.0-30.0$ & 29.5 & 0.707 \\
$\mathrm{pH}$ & & $7.70-7.72$ & 7.71 & 0.014 \\
Conductivity & $\mathrm{ms} / \mathrm{cm}$ & $4.55-4.63$ & 4.59 & 0.057 \\
Odour & & & Acceptable & \\
Colour & & & Acceptable & \\
Alkalinity & $\mathrm{mg} / \mathrm{l} \mathrm{CaC0}{ }_{3}$ & $140-150$ & 145 & 7.071 \\
$\mathrm{Hardness}$ & $\mathrm{mg} / \mathrm{l} \mathrm{CaC03}$ & $455-468$ & 461.500 & 9.192 \\
$\mathrm{COD}$ & $\mathrm{mg} / \mathrm{l}$ & $3,000-5,473$ & $3,396.22$ & 783.681 \\
$\mathrm{BOD}$ & $\mathrm{mg} / \mathrm{l}$ & $954-2,401$ & $1,124.03$ & 478.952 \\
$\mathrm{Mg}$ & $\mathrm{mg} / \mathrm{l}$ & $65.22-65.91$ & 65.565 & 0.488 \\
$\mathrm{Na}$ & $\mathrm{mg} / \mathrm{l}$ & $594-609$ & 601.5 & 10.607 \\
$\mathrm{~K}$ & $\mathrm{mg} / \mathrm{l}$ & $1,342.5-$ & $1,384.3$ & 59.114 \\
& & $1,426.1$ & & \\
$\mathrm{Fe}$ & $\mathrm{mg} / \mathrm{l}$ & $0.375-0.538$ & 0.4565 & 0.115 \\
$\mathrm{Zn}$ & $\mathrm{mg} / \mathrm{l}$ & $0.168-0.184$ & 0.176 & 0.011 \\
$\mathrm{Cr}$ & $\mathrm{mg} / \mathrm{l}$ & $0.036-0.047$ & 0.0415 & 0.008 \\
$\mathrm{Cd}$ & $\mathrm{mg} / \mathrm{l}$ & $\mathrm{Not}$ Detected & Not Detected & \\
$\mathrm{Pb}$ & $\mu \mathrm{g} / \mathrm{l}$ & $0.138-0.352$ & 0.245 & 0.151 \\
$\mathrm{Ni}$ & $\mathrm{mg} / \mathrm{l}$ & 0.006 & 0.006 & \\
$\mathrm{Mn}$ & $\mathrm{mg} / \mathrm{l}$ & $0.165-0.185$ & 0.175 & 0.014 \\
$\mathrm{TS}$ & $\mathrm{mg} / \mathrm{l}$ & $1,352-2,900$ & 1,590 & 495.584 \\
$\mathrm{Sulphate}$ & $\mathrm{mg} / \mathrm{l} \mathrm{SO}{ }_{4}^{2-}$ & $0.05-0.06$ & 0.055 & 0.007 \\
$\mathrm{Phosphorous}$ & $\mathrm{mg} / \mathrm{l} \mathrm{P}$ & $2.00-2.33$ & 2.165 & 0.233 \\
\hline
\end{tabular}

During the initial stage of operation of the initial values for the infeed (100 times diluted) were 2850 $\mathrm{mg} / \mathrm{l} \mathrm{COD}, 1200 \mathrm{mg} / \mathrm{l} \mathrm{BOD}$ and $1900 \mathrm{mg} / \mathrm{l} \mathrm{TS}$. The initial SBR cycle produced an effluent with 374 
$\mathrm{mg} / \mathrm{l} \mathrm{COD}, 141 \mathrm{mg} / \mathrm{l} \mathrm{BOD}$ and $534 \mathrm{mg} / \mathrm{l} \mathrm{TS}$. During the acclimatisation period the decreased leachate dilution resulted in increase of SBR effluent BOD, COD and TS levels (Figures 2, 3 and 4).

The obtained results indicate that this biological treatment system was successful in removing the pollutants from the diluted leachate. The treatment system was designed with main focus of removal of COD, BOD and TS. These parameters were monitored for 109 days and the variation with time gives a clear indication regarding the improved quality of the effluent.

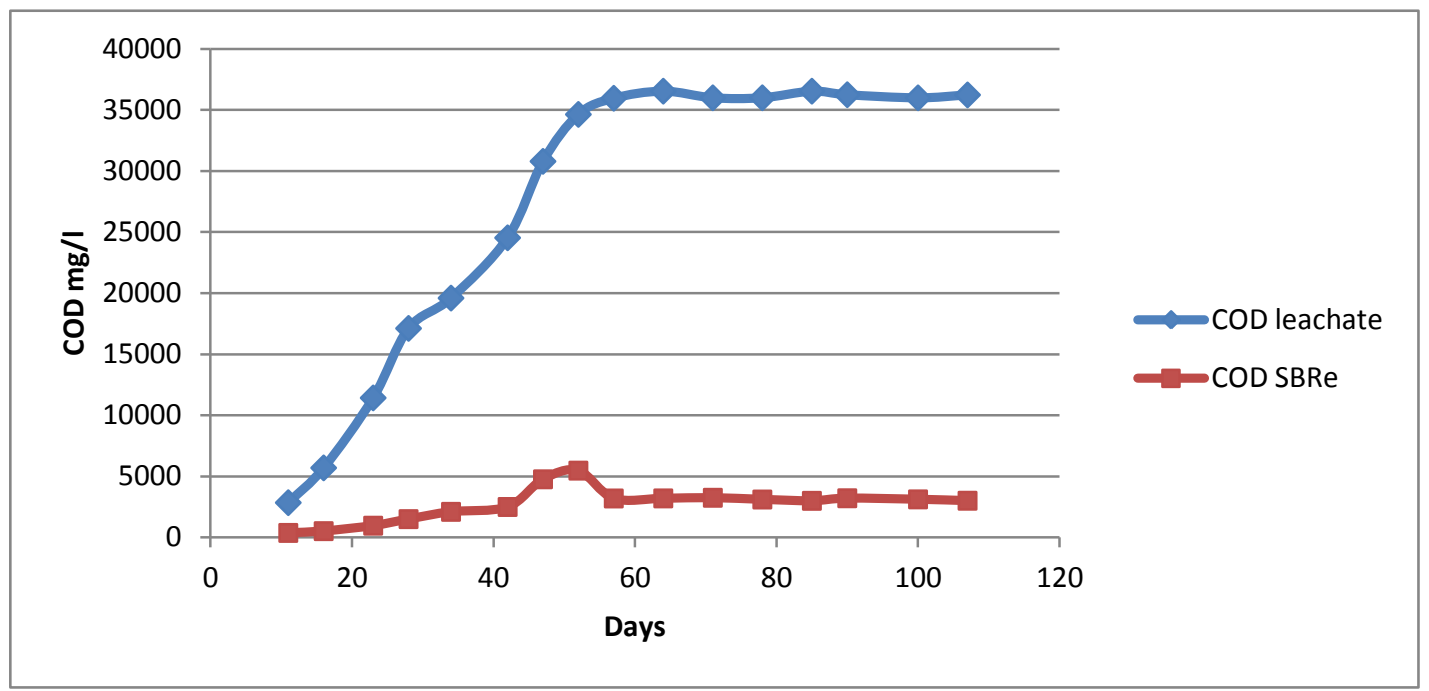

Figure 2: Variation of chemical oxygen demand with time.

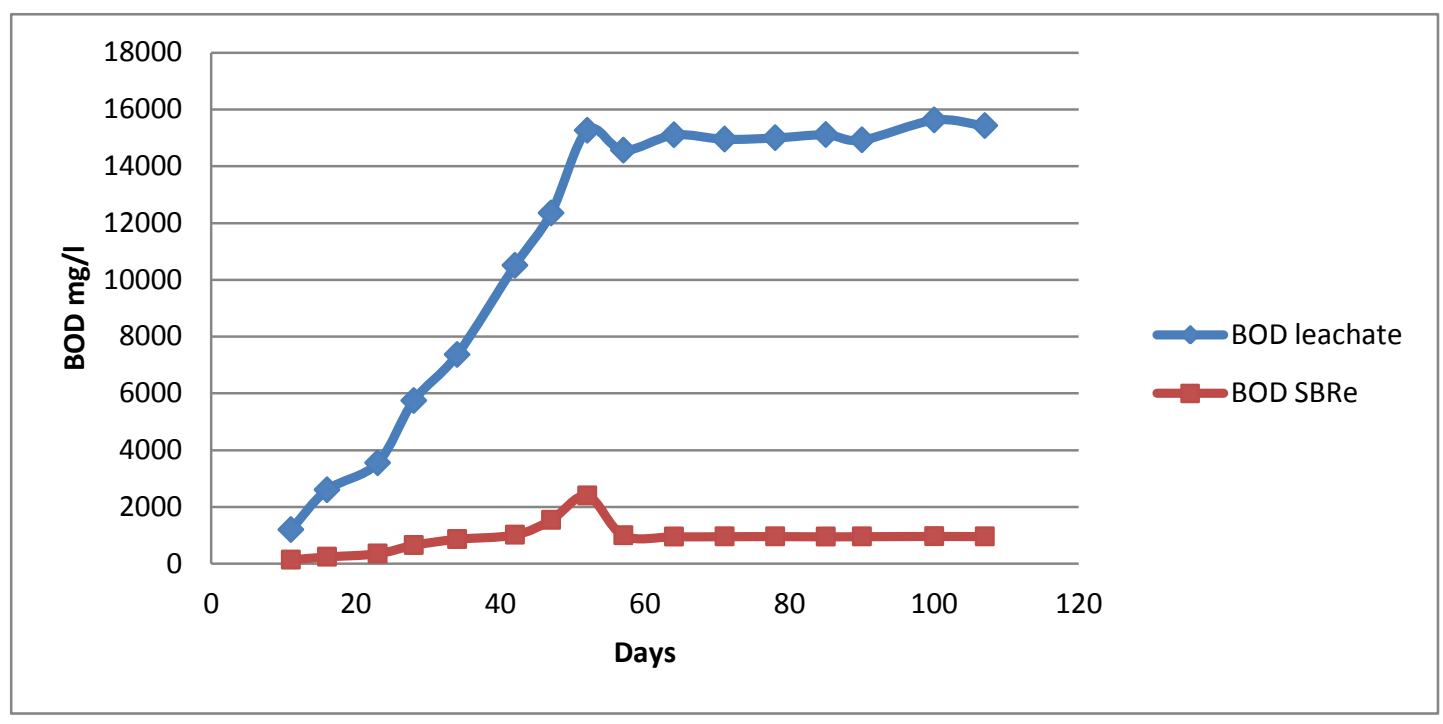

Figure 3: Variation of biological oxygen demand with time. 


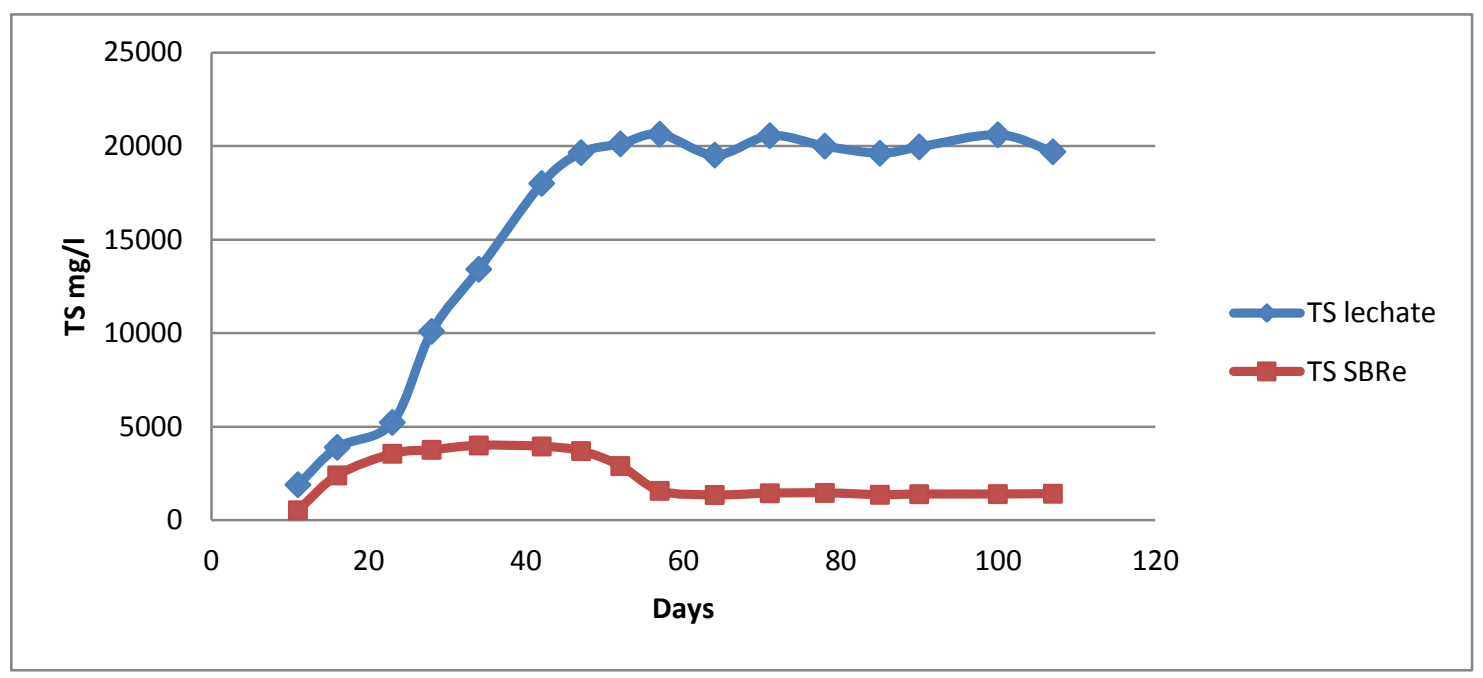

Figure 4: Variation of total solids with time.

The acclimatisation period lasted 54 days and during this period SBR effluent varied significantly at each dilution levels. After the acclimatisation period of 54 days, the influent quality and effluent quality obtained constant values for BOD, COD and TS. During the acclimatisation period it was observed that the effluent qualities increase to a maximum value prior to obtaining a constant value. This phenomenon occurs initially because the microorganisms in the activated sludge require time to adapt to the shock loads that is received and after adapting, consistent effluent quality was observed.

The steady state period lasted 55 days and during this period leachate temperature was $29-30^{0} \mathrm{C}$ and $\mathrm{pH}$ was 7.70-7.72. Alkalinity and the hardness of leachate were recorded as $140-150 \mathrm{mg} / \mathrm{CaCO}$ and 455-468 mg/l $\mathrm{CaCO}_{3}$ respectively. The COD ranged between 5,473-3,000 mg/l with ranges of 2,401-954 mg/l and 2,900-1,352 mg/l, for BOD and Total Solids. The metals Mg. Na, K, Ca, Fe, Zn, $\mathrm{Cr}, \mathrm{Pd}, \mathrm{Ni}$, and $\mathrm{Mn}$ were present in the SBR effluent. Cd was completely removed through the biological treatment. SBR effluent contained 0.05-0.06 mg/l Sulfate levels while the P levels were 2.00-2.33 mg/l.

The MLSS value range was 4,900-5,200 mg/l which exceeds the assumption of 3,850 mg/l for the conceptual design, indicating the healthy activated sludge microorganism population. The SVI of the SBR varied between 70-110 ml/g, indicating a desired sludge settlement with minimum filamentous growth. Rotifers, stalked ciliates, free swimming ciliates, flagellates and amoeboid are responsible for a good settling flow (Metcalf and Eddy, 2003).

The F/M ratio obtained varied between $0.818-0.824 \mathrm{~g} / \mathrm{g} . \mathrm{d}$ while the Volumetric BOD loading varied between $5.82 \mathrm{~kg} / \mathrm{m}^{3} \mathrm{~d}$ to $6.76 \mathrm{~kg} / \mathrm{m}^{3} \mathrm{~d}$. Due to the high pollutant levels in the infeed and low treat volume $(10 \mathrm{~L})$, higher F/M ratio and Volumetric BOD loading were observed. The removal efficiencies of the pollutants by the SBR are given in Table 4 .

Direct settlement of precipitates as a removal mechanism is unimportant. The major removal mechanism for metals with the highest percentage removals during the activated sludge process is the interaction of particulate associated metal with the settleable biological solids (Stephenson and Lester, 1987). 
Table 4: Operation efficiency of the Sequencing Batch Reactor.

\begin{tabular}{lcc}
\hline Parameter & Units & \% Removal Efficiency \\
\hline COD & $\mathrm{mg} / \mathrm{l}$ & 90.50 \\
$\mathrm{BOD}$ & $\mathrm{mg} / \mathrm{l}$ & 92.56 \\
$\mathrm{TS}$ & $\mathrm{mg} / \mathrm{l}$ & 92.10 \\
Conductivity & $\mathrm{mg} / \mathrm{l} \mathrm{CaCO}$ & 83.91 \\
Alkalinity & $\mathrm{mg} / \mathrm{l} \mathrm{CaC03}$ & 97.40 \\
Hardness & $\mathrm{mg} / \mathrm{l}$ & 82.17 \\
$\mathrm{Mg}$ & $\mathrm{mg} / \mathrm{l}$ & 80.45 \\
$\mathrm{Fe}$ & $\mathrm{mg} / \mathrm{l}$ & 94.24 \\
$\mathrm{Zn}$ & $\mathrm{mg} / \mathrm{l}$ & 63.43 \\
$\mathrm{Cr}$ & $\mathrm{mg} / \mathrm{l}$ & 31.69 \\
$\mathrm{Cd}$ & $\mu \mathrm{gg} / \mathrm{l}$ & 100.00 \\
$\mathrm{~Pb}$ & $\mathrm{mg} / \mathrm{l}$ & 99.58 \\
$\mathrm{Ni}$ & $\mathrm{mg} / \mathrm{l}$ & 100.00 \\
$\mathrm{Sulphate}$ & $\mathrm{mg} / \mathrm{l} \mathrm{SO}{ }_{4}^{2-}$ & 98.93 \\
$\mathrm{Phosphorous}$ & $\mathrm{mg} / \mathrm{P} \mathrm{P}^{2-}$ & 71.43 \\
\hline
\end{tabular}

According to Metcalf and Eddy (2003), typical design parameters for the SBR are 10-30 day SRT, 0.04-0.1 kgBOD/kgMLVSS.d F/M ratio, 2000-5000 mg/l MLSS and 15-40 hours Hydraulic Retention Time. The SBR parameters (Table 2) were designed for the treatment of $10 \mathrm{~L}$ of infeed which directly affect the sludge retention time, the BOD loading rate, F/M ratio and the tank dimensions. Increasing the treatment volume per cycle improves the above parameters to the desired optimum SBR operational levels but due to practical limitations, the optimum levels could not be obtained for some SBR parameters.

The SBR was also designed with many assumptive parameters for raw leachate, leading to overdesigned SBR. The Final effluent qualities are used to obtain the desired optimum conditions for SBR with the diluted infeed.

Many studies have been conducted for leachate diluted with water or for raw leachate. The treatment of leachate using different ratios of domestic wastewater has received very little attention. The leachate is deficient in nitrogen and phosphorous but by mixing it with nitrogen and phosphorous rich domestic wastewater, result in a more desirable nutrient composition. Domestic waste water has often contain considerably lower COD and BOD values compared to leachate and mixing the two waste steams would result in an effective dilution of the leachate and subsequently "easier" treatment (Raina, 1984).

The study was conducted to assess the feasibility of the usage of the Sequencing Batch Reactor (SBR) in the treatment of the landfill leachate up to the speculated water quality levels in the draft report of "Proposed Sri Lankan standard for landfill leachate to be disposed to the inland waters" (Table 5). The SBR unit alone could be used for the treatment of leachate, if the proposed standards are met by the SBR effluent.

The final SBR effluent characterisation revealed that the opted dilution does not result in the desired effluent quality. The higher dilution levels will result in increasing the volume of waste therefore further treatment of the leachate using a Constructed wetland was considered. 
Table 5: The final SBR effluent quality comparative to the proposed Sri Lankan standard.

\begin{tabular}{lcc}
\hline Parameter & $\begin{array}{c}\text { Standard value proposed based on typical } \\
\text { scenarios present in wet season }\end{array}$ & $\begin{array}{c}\text { The final quality of SBR } \\
\text { Effluent }\end{array}$ \\
\hline pH & $6.0-8.5$ & 7.7 \\
TSS & Max. $100 \mathrm{mg} / 1$ & $1,590 \mathrm{mg} / \mathrm{l}$ \\
BOD $_{5}$ & Max. $80 \mathrm{mg} / \mathrm{l}$ & $1,124 \mathrm{mg} / \mathrm{l}$ \\
COD & Max. $1,000 \mathrm{mg} / 1$ & $3,396 \mathrm{mg} / \mathrm{l}$ \\
Total Phosphorus & Max. $8 \mathrm{mg} / \mathrm{l}$ & $2.2 \mathrm{mg} / \mathrm{l}$ \\
Colour & Be removed as practical as possible & Acceptable \\
\hline
\end{tabular}

Artificially constructed wetlands easily remove many undesirable pollutants from wetland therefore gaining acceptance as a low cost treatment. Sedimentation removes Suspended Solids physically while removing dissolved nutrients, BOD, heavy metals and potentially harmful anthropogenic compounds through geochemical and biological processes (Williams and Adamsen, 2008).

\section{Conclusion}

SBR is an efficient and robust strategy in treatment of diluted leachate. A high removal efficiency of the pollutants, present in the leachate was observed during the SBR treatment. The dilutions of leachate in the dumpsites using municipal wastewater, groundwater or rainwater were identified as the most cost effective dilution methods. The effluent from the SBR was proposed to be further treated using a constructed wetland before releasing to surface water.

The dilution of the leachate was done with tap water during the experiment. In a practical situation use of the chlorinated tap water is not economically viable for a treatment plant, therefore leachate dilution using municipal waste water was identified as the main option.

\section{References}

Chian, E.S. and DeWalle, F.B. 1975. Compilation of methodology for measuring pollution parameters of landfill leachate. US Environmental Protection Agency, Office of Air, Land, and Water Use, Municipal Environmental Research Laboratory.

Fetter, C.W. 2001. Applied hydrogeology (Vol. 3, No. 3). Upper Saddle River, NJ: Prentice Hall.

Ifeanyichukwu, M.J. 2008. New Leachate Treatment Methods.

Metcalf, L., Eddy, H. and Tchobanoglous, G. 2003. Wastewater engineering: treatment, disposal, and reuse. McGraw-Hill.

Raina, S. 1984. Combined treatment of landfill leachate and domestic sewage. Ph.D. dissertation, University of British Columbia.

Renou, S., Givaudan, J., Poulain, S., Dirassouyan, F. and Moulin, P. 2008. Landfill leachate treatment: Review and opportunity. Journal of hazardous materials, 150(3): 468-493.

Stephenson, T. and Lester, J. 1987. Heavy metal behaviour during the activated sludge process II. Insoluble metal removal mechanisms. Science of the total environment, 63: 215-230.

Welander, U., Henrysson, T. and Welander, T. 1998. Biological nitrogen removal from municipal landfill leachate in a pilot scale suspended carrier biofilm process. Water Research, 32(5):15641570.

Williams, C. and Adamsen, F. 2008. A low-cost three-dimensional sample collection array to evaluateand monitor constructed wetlands. Ecological Engineering, 33(1): 83-90.

XU, S., HE, P., LU, F., LI, M. and SHAO, L. 2009. Transformation of organic matters in fresh leachate during anaerobic degradation under long hydraulic retention time. Journal of Environmental Sciences, 21(9): 1302-1308. 